\title{
The Impact of WTO on Food Security System of India
}

\section{OPEN ACCESS}

Manuscript ID:

ASH-2020-08013208

Volume: 8

Issue: 1

Month: July

Year: 2020

P-ISSN: 2321-788X

E-ISSN: 2582-0397

Received: 08.05.2020

Accepted: 20.06.2020

Published: 02.07.2020

Citation:

Aparnapandey, and Poonam Singh. "The Impact of WTO on Food Security System of India." Shanlax International Journal of Arts, Science and Humanities, vol. 8 , no. 1,2020 , pp. $79-83$.

DOI:

https://doi.org/10.34293/

sijash.v8i1.3208

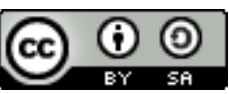

This work is licensed under a Creative Commons Attribution-ShareAlike 4.0 International License
Aparna Pandey

Research Scholar, M.J.P Rohilkhand University, Bareilly, Uttar Pradesh, India

D https://orcid.org/0000-0001-8734-3011

\section{Poonam Singh}

Associate Professor, S.R.S Girls PG College, Bareilly, Uttar Pradesh, India

\section{Abstract}

The Indian agricultural sector has experienced major transformation after the formation of WTO, which came into existence in 1995 with several new rules for international trade. The paper is concerned with the impact of WTO in the Indian context with a purpose to study how much food security has been provided after the formation of WTO? The paper also examines the stand of Indian WTO policies on agriculture and food security and judge India's position on WTO policy on agriculture and food security.

Keywords: WTO, Food Security, Government Programme, Food Security Act and

Public Distribution System.

\section{Introduction}

The concept of food security is defined as not only physical and economic access to food that meets people's dietary needs but also their food preferences. The definition emphasizes both these essential elements of food supply (availability) and demand (access). Therefore, food security is simply a look of access to just enough food. The extension of the definition focuses on the main issues and underlying conceptual frameworks that were ignored in previous definitions. Some specific studies have focused on (Salih, 1994; Pilly \& Kumar, 2018; Narayan, 2013; Chandra, 2014 and George \& Mckay 2019) that there is inequality in the distribution of income and wealth, and inter annual differences and inequalities in adequate dietary efficiency.

The present paper analyses the stand of India on WTO policies on agriculture and food security and the efforts of India to achieve food security. To analyze this purpose, we look at the attempts for the distribution of food grains to make sure food security for all and encountered problems there. The paper is divided into four sections. The first section is described food security and WTO. Section second explain food security in India. The third section discusses Food Security Act. Section fourth is related to the government plan for food security. Lastly, concluding remarks are described in section fifth.

\section{Food Security and WTO}

Agreement on agriculture came into existence in 1995, and it is one of the most important components of the WTO frame work of international trading rules. Its goal was to reduce the high level of protectionism in international agriculture that would benefit poor consumers in importing countries and benefit from trade for export to farmers. (Narayan 2013) But their asymmetric design has a different impact on developing and developed countries, the rules framed under the AOA has been the most controversial aspect of the regime 
of the WTO, from less developed countries. (Sharma 2016) Many elements of AOA are becoming weaker, which framework necessary for the right to food. Due to the ambiguity of the WTO rules, there exists a high degree of uncertainty in food security policy making, which discourages the state from implementing a comprehensive and innovative national right to food strategies. The step should be taken to establish a more definite and transparent policy that promotes the right to food. The aim of the present study is to help how agricultural trade agreements can provide a secure framework within which developing countries can purse effective policies to ensure their food security. (Roy \& Dubey 2016) It is an essential element of an agricultural policy that is sustainable and equitable.

\section{Food Security in India}

In most developing countries, food production is an important determinant of food security. Because in rural areas, most of the food-insecure people live, earn substantial income from agriculture and meet significant food requirements directly from their food production. (Salih 1994)

India and the many developing countries have the fear that with the liberalization of trade, they have given up tools to address both chronic and acute food insecurity. Therefore food security is key to negotiating agriculture at the WTO. There is a critical issue in India because a large section of the population is dependent on agriculture for their sustenance, and the poor consumers already spent an indispensable share of their income on food. The objective of the 2013 Act is to provide food and nutritional security to people by ensuring that people have access to sufficient Quality food at affordable prices. (Deshpande 2017) In our country, about $35 \%$ of the world's food insecure population lives, and $10-15 \%$ of the total households are food insecure, and they are not assured of getting at least two meals a day. (Roy, Emitriya and Dubey 2016)) The three dimensions that are important elements of agricultural policy and are sustainable and equitable are ecological security, livelihood security, and food security. And the current process of globalization underestimates all these dimensions, which are related to agricultural policy.
Many food items that are very much important for food security in developing countries, such as wheat, coarse grains, vegetable oils, sugar, oilseeds, etc. Are subject to high levels of export subsidies by developed countries. By artificially affecting international prices, these subsidies in developed countries reduce the agricultural incomes of skilled producers in importing countries and have a dismal impact on their livelihoods. To avoid these high trade distortions, members of a developing country will need an appropriate level of tariff protection.

\section{Government Programme for Food Security}

Since independence, India has got over the problem of famine and large scale deaths caused by starvation. Now annually, the country produces 93 million tonnes of wheat and 104 million tonnes of rice, (Annual report 2016-17) that is sufficient to meet the requirements of the public distribution system. The public distribution system is an important part of government policy for food management. It has developed gradually into a system for the distribution of food grains at economical prices. The main goal of food management is the distribution of food grains at economical prices to the consumers special to the weaker section of the society by purchasing food grains from the farmers at remunerative prices and also the maintenance of food buffers for food security, price stability. The public distribution system is run as a join responsibility of the central and state governments. Each year government announces Minimum Support Prices to favor the farmers and remove the exploitative middle men. Under the public distribution system, mainly rice, wheat, coarse grains are distributed. Ration Care System in India in India is another effort to establish food security. It is an important document and like a passport to a world of benefits that the government declares for the poor (Shetty 2014).

As of 1997, PDS has provided food security to all without any specific goal. As a result, it was widely criticises for its failure. To serve the population below the poverty line and lack of accountability and transparency, it was widely criticized. As a result, the need for fundamental reforms to target the public distribution system for the poor was realized. The Government of India, with a focus, launched a 
targeted public distribution system for the poor in June 1997. Six crore low-income families were to be covered under the TPDS and 72 lakh million tonnes food grains distribution annually. (Annual Report of the Dept. of Food and Public Distribution 2015)

A separate category under the Antyodaya Anna Yojana was introduced in December 2000, to make the distribution system more concentrated towards the very poor. Under the AAY, the poorest families in the BPL category were allocated wheat at a highly discounted rate of 2 ₹ per $\mathrm{kg}$ and rice at three ₹ per $\mathrm{kg}$; total plan coverage increased to 2.5 crore families by 2005-2006. The distribution of food grains per family per month was $25 \mathrm{~kg}$, which was increased to $35 \mathrm{~kg}$ per family by 2002. (Annual report of the Department of food and Public distribution 2015) Taking into account all inefficiencies inPDS, it is found that the GOI spend 3.65 ₹ through budgetary food subsidies to transfer 1 ₹ to the poor. (TPDS 2005) Reetikakhera describes, in a nine-state study, that eighty percent of beneficiaries felt that the TPDS was important to cover their family needs (Khera 2011). Food subsidy is given to beneficiaries at the central issue prices (CIP) under the National Food Security Act 2013. The CIP for wheat and rice is shown in the below figures. Food subsidy is calculated as the economic cost of purchasing food grains and the difference between their CIP.

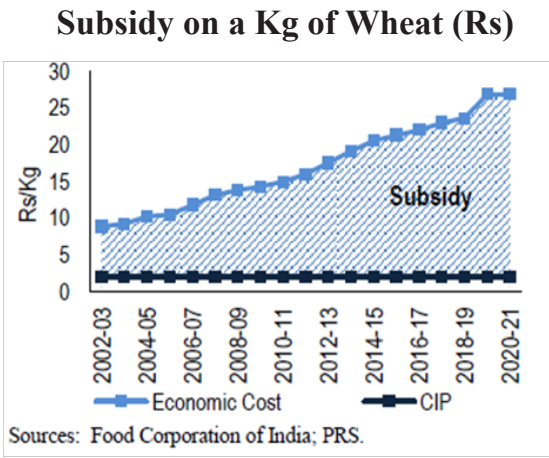

Subsidy on a Kg of Rice (Rs)

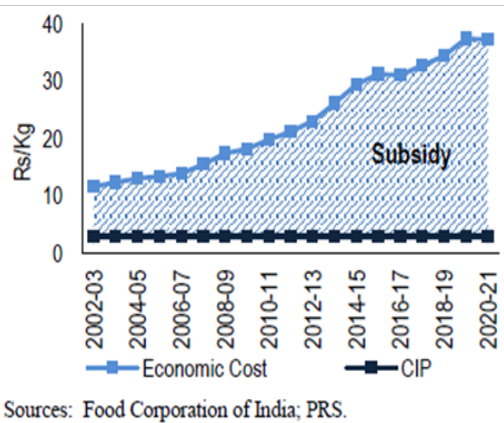

The economic cost of wheat has increased from ₹ 9 per kg in 2001-02 to ₹ $27 \mathrm{~kg}$ in 2020-21 and of rice from ₹ 11 per $\mathrm{kg}$ to ₹ 37 per $\mathrm{kg}$ over the same period. The CIP has not been revised. This has increased the difference between economic costs and CIP, leading to increased spending on food subsidies(PRS 2020). The above figure shows the trends in economic costs, CIP, and subsidy data for wheat and rice.

\section{The National Food Security Act}

India, with a population of billions, puts food security at the center of agricultural policy. The government of India has been taken important steps to maintain food security. And the National Food Security Act 2013 is one of them.

The Act makes provision to entitle every person belonging to priority households to receive every month from State Government under the Targeted Public Distribution System, five kilograms of food grains per person per month, at subsidized prices. This Act provides that eligible households shall be entitled to foodgrains at the subsidized price not exceeding ₹ 3 per $\mathrm{kg}$ for rice, ₹ 2 per $\mathrm{kg}$ for wheat and ₹ 1 per $\mathrm{kg}$. Such price as may be fixed by the Central Govt. from time to time, not exceeding-(i) the minimum support price for wheat and grains, and (ii) the derived minimum support price for rice, as the case may be.

The Act, on the other hand, provides that the households covered under Antyodaya Anna Yojana shall be entitled to receive thirty-five kilograms of foodgrains per household per month. The said entitlements at subsidized prices shall extend up to seventy-five percent of the rural population and fifty percent of the urban population. 
There is also provision for every pregnant woman and lactating mother to the meal, free of change, during pregnancy and six months after childbirth, through local Anganwadi, to meet the nutritional standards and to provide to such women maternity benefit of not less than rupees six thousand in such installments as ay be prescribed by the Central Government. It also entitles child up to the age of fourteen years- (i) age-appropriate meal, free of charge, through the local Anganwadi to meet the nutritional standard specified in Schedule II in the case of children in the age group six months to six years, (ii) one mid-day meal, free of charge every day, except on school holiday, in all school run by local bodies, Government aided school, to the children up to class VIII or within the age group of six to fourteen years, which ever is applicable, to meet the nutritional standards.

Under the Act, a duty has been imposed upon the State Govt.that the State Govt. shall, through local Anganwadi, identify and provide meals, free of charge, to children who suffer from malnutrition to meet the nutritional standards. The Act also envisages that eligible persons will be edited to receive such food security allowance from the concerned State Govt. to be paid to each person, in case of the supply of the entitled qualities of food grains or meals within the time and manner as prescribed by the Central Govt.

The Act, inter-alia, also provides that the Central Govt. and the State Govt. shall while implementing the provision of the Act and the schemes for meeting specific entitlements, give special focus to the needs of the vulnerable groups especially in a remote area and other areas which are difficult to access, hilly and tribal areas for ensuring their food security.

A duty has been imposed under the Act upon the Central Govt. , the State Govt. and local authorities that for the purpose of advancing and nutritional security, they have to strive to progressively realize the objectives which contain following provisions and certain other provisions also.

For advancing food security- Revitalisation of Agriculture (a) agrarian reforms through measures for security interest of small and marginal farmers. (b)increase in investment in agriculture, including research and development, extension services, micro, and macro irrigation, and power to increase productivity and production. (e) ensuring livelihood security to farmers by way of remunerative prices, access to inputs, credit, irrigation, power, crop insurance, etc. (d) prohibiting, unwarranted diversion of land and water from food production.

\section{Conclusion}

To increase public investment in agriculture in developing countries and to developing food security policies, there should be a renewed emphasis on the agricultural negotiations of the World Trade Organisation. Due to corporate control, the future of food and agriculture in India appears dismal under the rules of globalization. The corporate future will ensure that the farmers will be made contract farmers from owner farmers, seeds and water will be sold at higher prices as it will be the private property of global corporations. (Shiva 2004) Based on WTO rules, the government may fail to guarantee the right of food to their people in the future. But other features are being built based on alternative principal and practices, which will bring policy changes in the future. At the same time, it should also be stated that the food security system needs continuous improvement to ensure easy accessibility with good distribution mechanism, supply chain management, and price stability through fair price shops. Attention should be given to ensure that farming continues to be supported in the face threats like change in climate and monsoon failure. The state of agriculture production may look comfortable at present, but with a growing population, the situation may look become more difficult in the future. Therefore continuous efforts for food security in the country are a necessity for improvement, which will bring policy changes in the future.

\section{References}

Annual Report (2015-2016), Department of Food and Public Distribution, Ministry of Consumers Affairs, Food \& Public Distribution, Government of India.

Annual Report of the Department of Agriculture Cooperation and Farmers Welfare 2016-17, Ministry of Agriculture \& Farmers Welfare, Government of India. 
Deshpande, Tanvi. State of Agriculture in India, PRS Legislative Research, 2017.

"Food Security." Policy Brief, Food and Agriculture Organisation of the United Nations, no. 2, 2006.

George, Neetu, and Fiona H Mckay. "The Public Distribution System in India and Food Security in India." International Journal of Environmental Research and Public Health, vol. 16, no. 17, 2019.

Khera, Reetika. "Revival of the Public Distribution System: Evidence and Explanations." Economical and Political Weekly, vol. 46, no. 44-45, 2011.

Narayan, Sudha, "In the balance the national food security act vis a via the WTO Agreement on Agriculture", Indra Gandhi Institute of Development Research, Mumbai, 2013.

National Food Security Act 2013, Department of Food and Public Distribution, Ministry of food and Public Distribution.

Performance Evaluation of Targeted Public Distribution System (TPDS), Planning Commission, Government of India, New Delhi, 2005.
Roy, Emitriya and Usha Dubey. "Food Security in India Under WTO Regime." International Journal of Arts Humanities and Sciences, vol. 1, no. 21, 2016, pp. 44-51.

Salih, Siddig A. "Food Security in East and Southern Africa." Nordic Journal of African Studies, vol. 13, no. 1, 1994, pp. 3-27.

Sharma Sachin Kumar. The WTO and Food security: Implications for Developing Countries, Springer, 2016.

Shetty, Mayur. Ration Cards Out, Aadhar in to Open Bank Accounts, The Times of India, 2014.

Shiva, Vandana. "The Future of Food: Countering Globalisation and Recolonisation of Indian Agriculture." Futures, vol. 36, no. 6, 2004, pp. 715-732.

The State of Food in Security in the World, Food and Agriculture Organisation of the United Nations, 2015.

Tiwari, Suyash. Demand for Grants 2020-21 Analysis : Food and Public Distribution. PRS Legislative Research, 2020.

\section{Author Details}

Aparna Pandey, Research Scholar, M.J.P Rohilkhand University, Bareilly, Uttar Pradesh, India.

Email ID: pandey.aparna23@gmail.com.

Poonam Singh, Supervisor, Associate Professor, S.R.S Girls PG College, Bareilly, Uttar Pradesh, India.

Email ID: poonam.kva@gmail.com. 